\title{
Sustainability through Informality
}

\author{
Cristina Dreifuss-Serrano ${ }^{1}$
}

\begin{abstract}
In precarious environments, such as squatter settlements, sustainability can be achieved as an economic resource. It is important, however, to start with assuring a sense of belonging in the members of the communities. Through observation in squatter settlements and conversations with their inhabitants, this paper presents a view on informal sustainability through participative processes. We argue that if we begin by looking at cultural sustainability, people's sense of belonging becomes a key factor in taking care of the environment. We aim to demonstrate that even if squatter settlements are regarded as areas of conflict in terms of pollution, occupation of the land, and waste disposal, through informal processes people can achieve a degree of awareness that will not only result in sustainable practices, but that can also propose new creative ways to achieve them, with economical considerations in mind.
\end{abstract}

Keywords: Cultural sustainability, informality, human development, squatter settlements, identity

\section{Introduction}

"I]n a context in which the relation between capital and buman activity is repeatedly renegotiated, let us hope that ecological, feminist and anti-racist activity will focus more centrally on new modes of production of subjectivity: that is to say, on modes of knowledge, culture, sensibility, and sociability - the future foundations of new productive assemblages - whose source lies in incorporeal systems of value.” (Guattari, 1989, pág. 138).

Traditionally, squatter settlements have been regarded as conflictive from many points of view. Their origins are mostly in an illegal occupation of land, and soon they become communities based on informal economies, that evade taxes and can be risky both for their inhabitants and for the city, because of constructive precariousness and social segregation. From an ecological point of view, poverly linked to squatter settlements "pollutes the environment, creating environmental stress in a different way. Those who are poor and hungry will often destroy their immediate environment in order to survive: They will cut down forests; their livestock will overgraze grasslands; they will overuse marginal land; and in growing numbers they will crowd into congested cities. The cumulative effect of these changes is so far-reaching as to make poverty itself a major global scourge." (United Nations World Commission on Environment and Development (WCED), 1987, pág. 29). This opinion is shared by more recent authors (Davis, 2006; Pearlman, 2010; Auyero, 2014), who have pointed out the environmental and health risks posed by these types of human settlements.

Sustainable development "requires meeting the basic needs of all and extending to all the opportunity to satisfy their aspirations for a better life." (United Nations World Commission on Environment and Development (WCED), 1987, p. 43). This implies, not only careful management of current situation's resources (Towse, 2003, pág. 183), but moreover is a "development which meets the needs of the present without compromising the ability of future generations to meet their own need" (United Nations World Commission on Environment and Development (WCED), 1987).

An ecologic agenda that seems to require from people a series of change of habits are rarely accepted by communities, unless regulations and sanctions are put in place (Kwinter, 2013). In 
marginal populations, where even existing regulations are rarely complied, premises regarding environmental issues rarely leave the realm of theory, because of much more urgent survival and wellbeing needs .

However, we have observed that through everyday practices aiming to save money and gain comfort, inhabitants of informal settlements look for a more rational use of the available resources. These practices begin to happen after the occupation of the territory and a certain feeling of security in terms of belonging; they are forged alongside with community and citizenship.

Through case studies in peripheral communities in Metropolitan Lima, we identified spontaneous activities and attitudes which combine cultural and environmental sustainability. Even if these actions are not always systematic, we believe that it is possible, through the identification of the underlying logics, to promote sustainable policies that take into consideration not only environmental aspects, but especially social and cultural ones. Taking into consideration the three pillars of sustainable development - economic development, social equity, and environmental protection (Drexhage \& Murphy, 2010, pág. 2) - cultural sustainability should be the foundation for guaranteeing a better attitude towards environmental protection and people's responsibility.

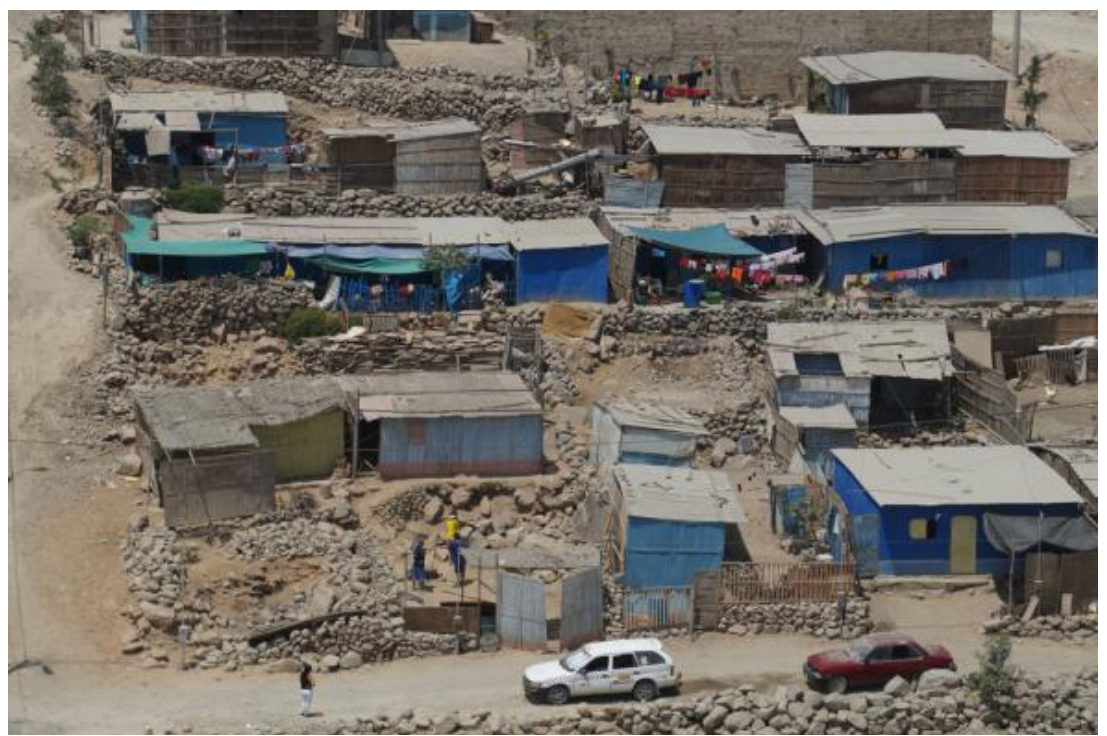

Fig 1: A small neighbourhood in Manchay, a squatter settlement east Lima.

\section{Informal Economic Sustainability}

Mrs. Raquel tells us that one has to be very careful with trash. She points at a large plastic bag and indicates that there is where plastic bottles and containers should go, while the rest, "the trash", has to be somewhere else. Once a week, Mrs. Raquel's husband takes all the collected plastic containers downtown. Few kilometres from the historic centre of Lima, in the degraded banks of Rimac river, "recyclers" meet to sell the collected plastic to factories, by ton. Some of these recyclers walk through the wealthiest neighbourhoods in the city and dig in the trash cans in parks and private residences, looking for the precious plastic bottles. Policemen look at them indulgently, and only if a neighbour requests it, they chase the recycler away.

This sort of job, defined as 'outworking' or 'homeworking' (UN-Habitat, 2003, pág. 101) is a very common practice for poor households. Even though it is a very criticized practice because it 
might lead to exploitation of the workers by the formal sector, it constitutes a profitable economic activity that does not require special knowledge or a large economic investment. Even children can take part in the pickup. Thus, the recycling, starting as a mere economic activity, becomes a second nature to dwellers, and objects are perceived by its capacity to be reutilised, even if benefits are not always economic or immediate.

Some of the characteristics of informal economy are working with small-scale units, usually based on family ties; few capital or skills required to enter; learning through informal apprenticeships; informal, flexible internal organization and hierarchy; informal relationship with clients, suppliers and authority; and combination of different activities and the possibility to adapt them according to need (UN-Habitat, 2003, págs. 100-101). While many of these characteristics might be used by the formal economic sector to take advantage of the poor, in most cases the very characteristics of informal economy constitute its strength.

A small shop can serve to multiple purposes or offer different goods depending on the needs of the close-by population, with whom it is closely related; it usually employs local materials and/or local workforce; it can work as a gathering space thus becoming an important social landmark for the neighbourhood; and finally, it can even change of trade altogether if there is a different need or if external economic circumstances that require it.

Flexibility, intrinsically linked to informal processes (Brillenbourg, Feireiss, \& Klumpner, 2005; Mehrotra, 2012), can become an asset for adaptation to varying environmental conditions, while giving inhabitants a skill for spotting opportunities regardless the precariousness of the context.

\section{Awareness - Working with External Actors}

Pierina and Carolina have asked their friends through their private Facebook accounts to collect containers, plastic recipients, cardboard boxes and tins. The materials (several bags) is taken by the two women to Ruwasunchis, a NGO that has been working with the community of San Pablo Mirador (Manchay, east Lima) for almost 10 years. Pierina and Carolina are volunteers in charge of a group of children during the weekends.

The neighbourhood children work with the gathered materials building utilitarian and decorative objects. The experience has two objectives: first, to reinforce in the children an awareness of recycling and reusing; second, to produce objects for displaying in other, more consolidated areas of the city, aiming for possible financing sources for future projects.

The children mothers have their own group, "Las tejedoras de Manchay", and they produce handknitted accessories to sell. The members of the NGO have helped them place their products in different areas of the city, where they can make a bigger profit.

Poverty and precarious environments pose needs to be resolved in groups. Community ties become stronger in the informal city than in more developed areas, and through these groups there can be internal and external dialogues aiming for sustainable development (UN-Habitat, 2003, pág. 151). Alternatively, the proliferation of NGOs alongside religious and government initiatives in recent years points towards a different way to asset squatter settlements. Where government policies have failed or were unable to cope with the scale of problems, minor initiatives, participative and based on multidisciplinary dialogue, seem to have more success, even if not very noticeable at first. 


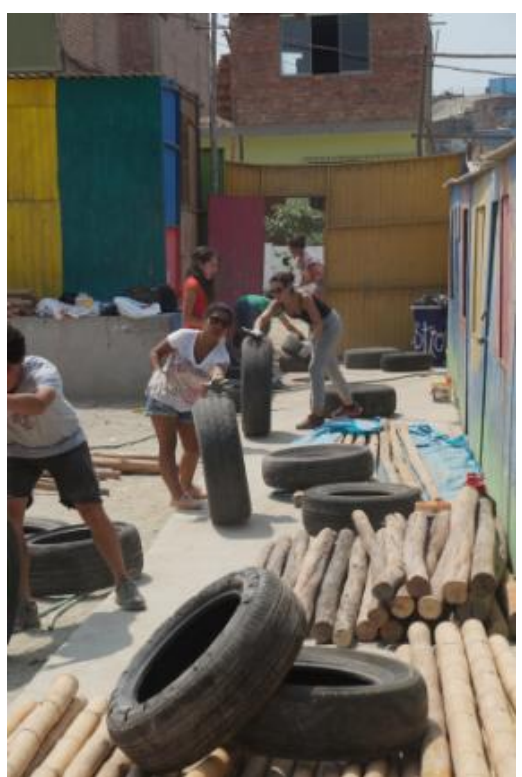

Fig 2: Volunteers and members of the community working on improving the community centre

Private and state groups have understood the importance of the formal value in unconsolidated contexts. The building of roads, paths, stairs or sport facilities is not enough (Avellaneda, 1999). Programmes like Barrio Mío (organized by the city council of Lima) or Favela-Bairro in Rio de Janeiro (Segre, 2012) or the work of several NGOs, which start with participative processes, take into account not only what is necessary for the neighbourhood from a pragmatic point of view, but also what is required by the community and their subjective preferences, considering the aesthetic dimension of public spaces as means to consolidate people's involvement with the neighbourhood.

In order for people to care for the place they inhabit, it is important not only the construction of community ties, but also the work on the place itself. The sense of belonging is important for people to start to care not only about their household's wellbeing, but for the community's as well. Placemaking through participative processes, whose goal is "to produce a physical environment under normative notions of livability, public realm, social and economic equity, diversity, sustainability, and aesthetic quality" (Burga, 2008, pág. 15), becomes an asset in the establishment of community practices that can lead to sustainability.

\section{Subjective Priorities}

A group of volunteer landscape architecture students, from the US, is going to spend a short stage at Manchay. Its project begins with great frustration. After learning about the desert conditions of the site, where there is no public water system and people has to pay up to five times the regular price for it, the students think it is irresponsible to propose green areas: "People cannot afford to waste water in ornamental plants, when there are more pressing needs". This is far from the truth. Gardens, even if they have only an ornamental, non-food purpose, is regarded as valuable and very important. Plants are chosen because of its resistance to high temperatures and scarcity of water, or because of their utility. To water them, people use gray water from cooking or cleaning. It is even frequent to find small gardens near the kitchen, that started spontaneously and were taken care of later. 


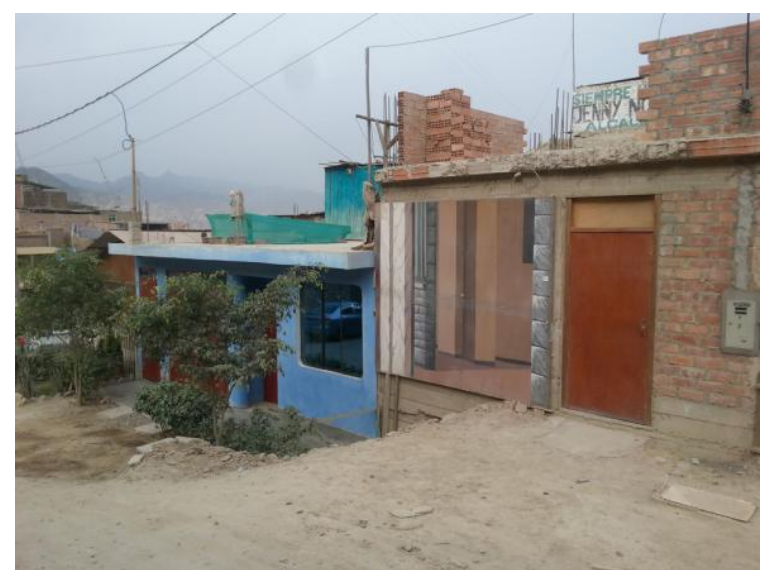

Fig 3: Front gardens and paintings outside houses in a squatter settlements.

"Households in informal settlements use less than half of the amount of water as the average usage in the same cities, owing to poorer availability and greater costs. The median water price in informal settlements is almost five times the average price." (UN-Habitat, 2003, pág. 114). This tough reality makes green areas much more valuable. They become landmarks and the sign of a "proper household", and ultimately, a source of pride.

\section{Sustainability and Aesthetics - A Road towards Dignity?}

Hugo, 10 years old, is the proud owner of a "Tini”" (tierra de niños, land of children). It is a small garden, $1 \mathrm{~m}^{2}$ approximately, in the exterior area of his parents' house. The implementation of "Tinis" is supervised by a volunteer, forest engineer, that visits this and other similar gardens, managed by kids and grown-ups alike. Adults mostly not only want to have a decorative garden, but also aim for economic profit. Vegetables are for family consumption or trade between neighbours. The people in charge of "Tinis" tend to go beyond gardening: fences and houses are painted in bright colours. One can recognise the houses in the neighbourhood where these gardening occurs because of its external image.

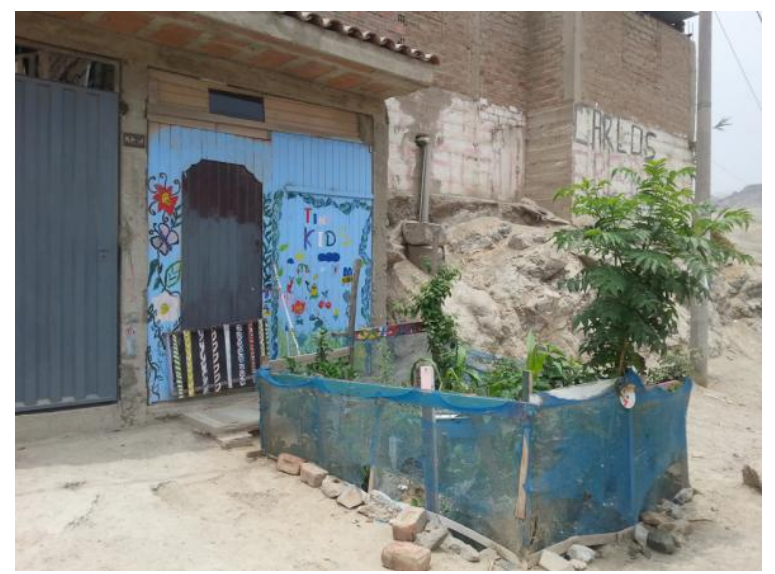

Fig 4: Tini (tierra de niños, land of children) at Manchay. 
Pragmatic aspects, through very important, are not enough for the community. As mentioned lines above, the emotional, the affective, is required in order to establish links between dwellers and the occupied territory, that would eventually lead to its consolidation (Habraken, 1998). In order to achieve true sustainability, a sense of belonging and an identity between neighbours and their settlement must come first. We argue that the urban aesthetic experience, an everyday phenomenon that can be altered and improved, could work as a catalyst for a strong sense of belonging and thus, a willingness of taking care of the dwelling and its surroundings.

In order to create environmental awareness, aesthetics can work as a link between the 'human' and the 'natural' (Kwinter, 2013). "Aesthetics can have an affective quality - triggering emotional responses and revealing sensory possibilities and understandings that activate novel forms of subjectivity." (Rios, 2014, pág. 176). There is a natural relationship between this aesthetic approach and ethics. The image of the places people dwell carry affective qualities; planners and designers, when taking this into consideration, might propose better ways for inhabitants to relate with themselves and the place they live in.

\section{Final Thoughts}

The practices described show us resilience in precarious urban situations, and how even in squatter settlements, there is a possibility for sustainable development, if local characteristics are take into consideration. Most of the actions seen in the visited settlements begin with economic needs. In time, though, other values arise and the decisions made in relation to the environment escape the realm of the strictly pragmatic.

It is important then to consider inhabitants' cultural capital. "An item of cultural capital can be defined as an asset that embodies or gives rise to cultural value in addition to whatever economic value it might possess." (Throsby, 2006, pág. 3). Organised groups inside a community, aesthetic and cultural practices, leisure activities and even economic resources sum up to individuals' cultural capital and thus become the way to dialogue with the environment. Once processes are interiorised, ecological practices such as recycling or urban agriculture become part of this cultural capital and can be replicated and enhanced. Ideally, a culture of sustainability can be build, by strengthening the small everyday practices.

Ecological postures that don't take the social aspects of communities into account, are likely to fail due to a lack of understanding and communication (Kwinter, 2013). For the dwellers of squatter settlements, such discourses might even have a detrimental effect, where ecology is regarded as some sort of imposition with no immediate gain.

It is important to start working with the situation as it is (Guattari, 1989), taking into account the contemporary conditions not only in terms of objectives but especially regarding the resources we dispose to work towards sustainable development. Through the understanding and reinforcement of cultural and social aspects in precarious communities, sustainable practices can be achieved, based on local logics and subjectivities.

\section{References}

Auyero, J. (2014). Toxic Waited. Flammable Shantytown Revisited. In B. Fischer, B. McCann, \& J. Auyero, Cities from Scratch. Poverty and Informality in Urban Latin America (pp. 238-262). Durham: Duke University Press.

Avellaneda, P. G. (1999). Lima: Cuando la sostenibilidad no es sólo una cuestión medioambiental. Ecología Politica, No 17, 73-81.

Brillenbourg, A., Feireiss, K., \& Klumpner, H. (2005). Informal city. Caracas Case. München: Prestel.

Burga, H. F. (2008). Traditions of Placemaking and Fundamentalisms of Practice: The New Urbanism in the Context of Globalisation. Traditional Dwellings and Settlements Review, Vol. 20, No. 1, 15.

Davis, M. (2006). Planet of Slums. London: Verso. 
Drexhage, J., \& Murphy, D. (2010). Sustainable Development: From Brundtland to Rio 2012. New York: United Nations.

Guattari, F. (1989). The Three Ecologies. New Formations, No 8, 131-147.

Habraken, N. J. (1998). The Structure of the Ordinary. Cambridge: MIT Press.

Kellett, P. (2011). Informal settlements and the construction of everyday life. Informality: Re-Viewing Latin American Cities. Cambridge: The Centre for Research in the Arts, Social Sciences and Humanities.

Kwinter, S. (2013). Notes onthe Third Ecology. In M. Mostafavi, \& G. Doherty, Ecological Urbanism (pp. 94105). Cambridge, MA: Harvard University, Graduate School of Design - Lars Müller Publishers.

Mehrotra, R. (2012). Foreword. In F. Hernández, P. Kellett, \& L. K. Allen, Retbinking the Informal City. Critical Perspectives from Latin America (pp. ix-xiv). New York: Berghahn Books.

Pearlman, J. (2010). Favela. Four Decades of Living on the Edge in Rio de Janeiro. Oxford: Oxford University Press.

Rios, M. (2014). Learning from informal Practices: Implications for Urban Design. In V. Mukhija, \& A. Loukaitou-Sideris, The Informal American City. Beyond taco trucks and day labor (pp. 173-192). Cambridge, MA: The MIT Press.

Segre, R. (2012). Formal-Informal Connections in the Favelas of Rio de Janeiro: The Favela-Bairro Programme. In F. Hernández, P. Kellett, \& L. K. Allen, Retbinking the Informal City. Critical Perspectives from Latin America (pp. 163-180). New York: Berghahn Books.

Throsby, D. (2006). On the Sustainability of Cultural Capital. Faculty of Business and Economics, MacQuarie University, 1-16.

Towse, R. (2003). A Handbook of Cultural Economics. London: Edward Elgar Publishing.

UN-Habitat. (2003). The challenge of slums - Global report on urban settlements. London: UN-HABITAT Earthscan.

United Nations World Commission on Environment and Development (WCED). (1987). Our Common Future. London: Oxford University Press.

United Nations World Commission on Environment and Development (WCED). (1987). Our Common Future. London: Oxford University Press. 
